JURNAL RISET MAHASISWA AKUNTANSI

http://ejournal.unikama.ac.id/index.php/jrma

JRMA, Volume 6, No 2, Oktober 2018

\title{
PENGARUH KEPEMILIKAN MANAJERIAL, KEPEMILIKAN INSTITUSIONAL, FREE CASH FLOW DAN UKURAN PERUSAHAAN TERHADAP KEBIJAKAN HUTANG

\author{
(Perusahaan Manufaktur Sektor Industri Kertas yang Terdaftar \\ di BEI)
}

\author{
Nurul Puspitasari \\ e-mail:nurul.puspita32@gmail.com
}

\author{
Abdul Halim \\ Rita Indah Mustikowati \\ (Program Study Akuntansi, Fakultas Ekonomika dan Bisnis Universitas Kanjuruhan, Malang)
}

\begin{abstract}
ABSTRAK
Penelitian ini bertujuan untuk menguji dan menjelaskan pengaruh kepemilikan manajerial, kepemilikan institusional, free cash flow, dan ukuran perusahaan terhadap kebijakan hutang pada perusahaan manufaktur sektor industri kertas yang terdaftar di Bursa Efek Indonesia pada tahun 2010-2015. Jenis penelitian yang digunakan adalah explanatory research, dengan pengujian asumsi klasik, dan dianalisis menggunakan analisis regresi linier berganda serta menggunakan uji t untuk pengujian secara parsial. Jumlah sampel dalam penelitian ini sebesar 5 perusahaan, dan teknik pengambilan sampel menggunakan purposive judgement sampling. Variabelpenelitian ini terdiri dari kepemilikan manajerial, kepemilikan institusional, free cash flow, ukuran perusahaan sebagai variabel independen dan kebijakan hutang sebagi variabel dependen. Hasil penelitian menunjukkan bahwa kepemilikan manajerial, free cash flow dan ukuran perusahaan berpengaruh terhadap kebijakan hutang. Sedangkan kepemilikan institusional tidak berpengaruh terhadap kebijakan hutang.
\end{abstract}

Kata kunci- Kepemilikan Manajerial, Kepemilkan Institusional, Free Cash Flow, Ukuran Perusahaan dan Kebijakan Hutang

\begin{abstract}
This study aims to examine and explain the effect of managerial ownership, institutional ownership, free cash flow, and company size on debt policy in the paper manufacturing sector companies listed on the Indonesia Stock Exchange in 2010-2015. The type of research used is explanatory research, by testing classic assumptions, and analyzed using multiple linear regression analysis and using the test for partial testing. The number of samples in this study amounted to 5 companies, and the sampling technique used purposive judgment sampling. This research variable consists of managerial ownership, institutional ownership, free cash flow, company size as an independent variable and debt policy as the dependent variable. The results showed that managerial ownership, free cash flow and company size influence debt policy. While institutional ownership has no effect on debt policy.
\end{abstract}


Nurul Puspitasari, Pengaruh Kepemilikan Manajerial, Kepemilikan Institusional, Free Cash Flow Dan Ukuran Perusahaan Terhadap Kebijakan Hutang

Keynotes : managerial ownership, institutional ownership, Free Cash Flow, company size and debt policy

\section{PENDAHULUAN}

Tujuan suatu perusahaan adalah untuk meningkatkan nilai perusahaan, dengan cara pemilik atau pemegang saham mendelegasikan wewenang kepada manajer untuk mengelola perusahaan dalam mencapai tujuan yang diharapkan, salah satunya dalam hal kebijakan hutang. Kebijakan hutang merupakan suatu keputusan yang diambil oleh pihak manajemen untuk membiayai kegiatan operasional perusahaan, dimana pembiayaan tersebut berasal dari eksternal atau hutang (Fransiska, 2015:3). Kebijakan hutang harus dikelola dengan baik dengan cara memperhatikan proporsi penggunaan hutang. Menurut Jensen (1986:2) permasalahan yang berhubungan dengan suatu hutang yaitu permasalahan tentang biaya agensi yang berhubungan atas hutang yang disebabkan adanya kegiatan peminjaman dana oleh perusahaan dari pihak kreditur. Kegiatan ini menimbulkan permasalahan yang melibatkan pihak shareholder sebagai pemilik, pihak manajemen sebagai pengelola dan pihak kreditur sebagai pemberi pinjaman. Permasalahan yang melibatkan pihak-pihak yang terkait, disebut dengan konflik keagenan.

Konflik keagenan yang terjadi antara manajer dan pemegang saham tersebut akan menimbulkan agency cost. Selain itu menurut Tarjo dan Jogianto (2003:7) free cash flow (aliran kas bebas) juga dapat menimbulkan konflik keagenan yang menyebabkan timbulnya agency cost. Untuk mengurangi munculnya agency cost, dapat dilakukan dengan melibatkan pihak ketiga yaitu kreditur. Kreditur akan melakukan pengawasan melalui kebijakan hutang. Dengan adanya hutang maka perusahaan memiliki kewajiban untuk melakukan pembayaran secara periodik terhadap bunga dan pinjaman pokoknya, sehingga dapat mengurangi keinginan manajer menggunakan free cash flow (aliran kas bebas) untuk membiayai kegiatan yang tidak optimal (Jensen, 1986:4).

Menurut Agustian (2014:6) dengan adanya kepemilikan institusional maka perilaku manajer akan lebih terkontrol dengan baik oleh pihak pemegang saham eksternal. Kepemilikan manajerial juga bisa digunakan untuk meminimalisasikan timbulnya agency cost dengan cara mensetarakan kepentingan. Dengan adanya kepemilikan manajerial akan mensejajarkan kepentingan antara manajemen dengan pemegang saham sehingga manajer akan merasakan langsung tentang manfaat yang akan diambil dari keputusan yang benar dan merasakan kerugian apabila keputusan yang diambil salah terutama keputusan yang berhubungan dengan hutang. Dengan demikian, manajer akan semakin hati-hati dalam menggunakan hutang untuk kegiatan opportunistik yang dilakukannya.Menurut Patricia (2014:4), kebijakan hutang yang diambil perusahaan berkaitan erat dengan kemampuan perusahaan dalam mengembalikan hutangnya. Ukuran perusahaan menjadi salah satu tolak ukur kreditur dalam memberikan pinjaman dana dimana total aset dijadikan untuk mengukur bear kecilnya suatu perusahaan.

Berdasarkan penelitian yang dilakukan oleh Fransiska (2015) dan Saerang dkk (2015) yang menyimpulkan bahwa kepemilikian manajerial dan kepemilikan institusional berpengaruh signifikan terhadap kebijkan hutang. Sehingga, peneliti menambahkan dua variabel baru yaitu free cash flow dan ukuran perusahaan yang juga berpengaruh dalam kebijakan hutang. Penambahan dua variabel ini mengacu pada penelitian yang dilakukan oleh Tarjo dan Jogianto (2003) yang menyatakan bahwa kebijakan hutang merupakan salah satu kebijakan yang memunculkan konflik antara 
Nurul Puspitasari, Pengaruh Kepemilikan Manajerial, Kepemilikan Institusional, Free Cash Flow Dan Ukuran Perusahaan Terhadap Kebijakan Hutang

manajemen dan investor. Konflik ini berhubungan dengan free cash flow perusahaan. Dan dalam hasil penelitian Anggraini (2013) menyatakan bahwa ukuran perusahaan berpengaruh terhadap kebijakan hutang karena ukuran perusahaan akan menjadi faktor penentu berapa besar kebijakan keputusan pendanaan yang dilakukan.

Berdasarkan penelitian sebelumnya, penulis tertarik untuk meneliti lebih lanjut dengan menggunakan variabel kepemilikan manajerial, kepemilikan institusional, free cash flow, ukuran perusahaan untuk menguji dan menjelaskan dari keempat variabel tersebut manakah yang paling dominan berpengaruh terhadap kebijakan hutang.

\section{TINJAUAN PUSTAKA}

\section{Hutang}

Hutang (liabilities) merupakan kewajiban perusahaan masa kini yang timbul dari akibat peristiwa masa lalu (SAK, 2002:13). Hutang merupakan kewajiban perusahaan yang harus dipenuhi di masa sekarang dengan membayar sejumlah uang atau menyerahkan barang atau jasa akibat transaksi yang telah ditimbulkan di masa lalu.

\section{Kebijakan Hutang}

Kebijakan hutang merupakan keputusan yang diambil oleh manajemen untuk menentukan besarnya hutang dalam sumber pendanaannya yang berguna untuk membiayai kegiatan operasional perusahaan. Kebijakan hutang sering dilambangkan dengan debt to equity ratio (DER).

\section{Kepemilikan Manajerial}

Menurut Bodie, (2010:54) kepemilikan manajerial merupakan pemisahan kepemilikan antara pihak outsider dengan pihak insider. Kepemilikan manajerial merupakan kepemilikan saham manajemen dalam bentuk persentase. Dengan kepemilikan adanya kepemilikan manajerial akan membuat manajer lebih berhati-hati dalam pengambilan keputusan mengenai hutang.

\section{Kepemilikan Institusional}

Menurut Tarjo (2008:4) kepemilikan institusional adalah kepemilikan saham yang dimiliki oleh pihak institusi atau suatu lembaga seperti perusahaan asuransi, bank, perusahaan investasi, dan kepemilikan institusi lainnya. Kepemilikan institusioal merupakan kepemilikan saham institusi yang dinyatakan dalam bentuk persentase. Semakin tinggi tingkat kepemilikan institusional maka semakin tinggi pula tingkat monitoring terhadap kinerja manajemen.

\section{Free Cash Flow}

Menurut Kieso (2011:210) menyatakan arus kas bebas (free cash flow) adalah jumlah arus kas diskrosioner perusahaan untuk membli investasi tambahan, melunasi hutang, membeli saham treasury, atau hanya untuk menambah likuiditas perusahaan.

\section{Ukuran Perusahaan}

Menurut Ibrahim (2008:42), ukuran perusahaan adalah besar kecilnya suatu perusahaan yang dapat diukur dengan berbagai cara antara lain dengan total aset, log size, nilai pasar saham dan jumlah penjualan. Besar kecilnya suatu perusahaan akan berpengaruh dalam mendapatkan suatu pendanaan.

- Pengaruh Kepemilikan Manajerial Terhadap Kebijakan Hutang

Menurut Wahyu (2008:7) dengan adanya kepemilikan manajerial akan dapat mensejajarkan kepentingan antara pihak manajemen dan pihak pemegang saham, sehingga manajer dapat merasakan dan kerugian atas keputusan yang diambil mengenai hutang. 
Nurul Puspitasari, Pengaruh Kepemilikan Manajerial, Kepemilikan Institusional, Free Cash Flow Dan Ukuran Perusahaan Terhadap Kebijakan Hutang

Namun Anggraini (2013:17) menyimpulkan bahwa kepemilikan manajerial tidak berpengaruh terhadap kebijakan hutang. Hasil penelitian Fransiska (2015:13), Saerang dkk (2015:700) dan Santosa (2014:54) juga mendukung hasil penelitian tersebut. Dengan demikian, dapat ditentukan suatu hipotesis sebagai berikut:

\section{H1 : Kepemilikan manajerial berpengaruh terhadap kebijakan hutang}

- Pengaruh Kepemilikan Institusional Terhadap Kebijakn Hutang

Menurut Fransiska (2015:5) sekuritas perusahaan dapat menyamakan kepentingan insider dengan pihak ekstern dan akan mengurangi peranan hutang sebagai mekanisme untuk meminimumkan agency cost. Dengan tingkat kepemilikan institusional yang tinggi maka akan meningkatkan pengawasan terhadap kinerja yang dilakukan manajer agar lebih berhati-hati dalam menggunakan hutang dan menghindari berperilaku opportunistik. Dalam penelitian tersebut, Fransiska menyatakan bahwa kepemilikan institusional berpengaruh terhadap kebijakan hutang.

Pernyataan tersebut diperkuat dalam penelitian Yulianto (2010:40), Saerang dkk (2015:700) dan Bernice (2015:8) yang juga menyatakan bahwa kepemilikan institusional berpengaruh terhadap kebijakan hutang. Dengan demikian, dapat ditentukan suatu hipotesis sebagai berikut:

\section{H2 : Kepemilikan institusional berpengaruh terhadap kebijakan hutang}

- Pengaruh Free Cash Flow terhadap Kebijakan Hutang

Menurut Tarjo dan Jogianto (2003:16) menjelaskan bahwa pemilik perusahaan menginginkan free cash flow untuk meningkatkan kesejahteraan dan kos perusahaan yang dibiayai oleh hutang sedangkan manajemen menginginkan sebuah free cash flow untuk diinvestasikan pada proyek yang dapat menguntungkan di masa datang. Free cash flow mencerminkan keuntungan bagi para investor. Jika free cash flow dibagikan kepada para investor, manajemen harus mencari pendanaan lain dari luar untuk menjalankan kegiatan operasional. Pendanaan tersebut berupa hutang. Dengan demikian, dapat ditentukan suatu hipotesis sebagai berikut:

H3 : Free cash flow berpengaruh terhadap kebijakan hutang

- Pengaruh Ukuran Perusahaan Terhadap Kebijakan Hutang Menurut Anggraini (2013:7) besar kecilnya ukuran perusahaan itu akan menentukan untuk mendapatkan sumber pendanaan dari berbagai sumber. Pernyataan tersebut diperkuat dalam penelitian Bernice (2015:8) yang menyimpulkan ukuran perusahaan juga berpengaruh dalam kebijakan hutang. Dengan demikian, dapat ditentukan hipotesis sebagai berikut:

H4 : Ukuran perusahaan berpengaruh terhadap kebijakan hutang

- Vaiabel Yang Paling Dominan Terhadap Kebijakan Hutang

Menurut Tarjo dan Jogianto (2003:16) menyatakan bahwa kebijakan hutang merupakan salah satu kebijakan yang dapat memunculkan konflik kepentingan antara manajemen dan investor. Investor menginginkan free cash flow dalam rangka meningkatkan kesejahteraan dan kos perusahaan dibiayai oleh hutang, sedangkan manajemen menginginkan free cash flow diinvestasikan pada proyek yang menguntungkan dimasa datang. Sehingga, apabila free cash flow dibagikan kepada pemegang saham otomatis manajemen akan mencari pendanaan eksternal atau hutang untuk membiayai kegiatan operasional perusahaan.

Dengan demikian, dapat ditentukan suatu hipotesis sebagai berikut:

H5: Free cash flow berpengaruh dominan terhadap kebijakan hutang 


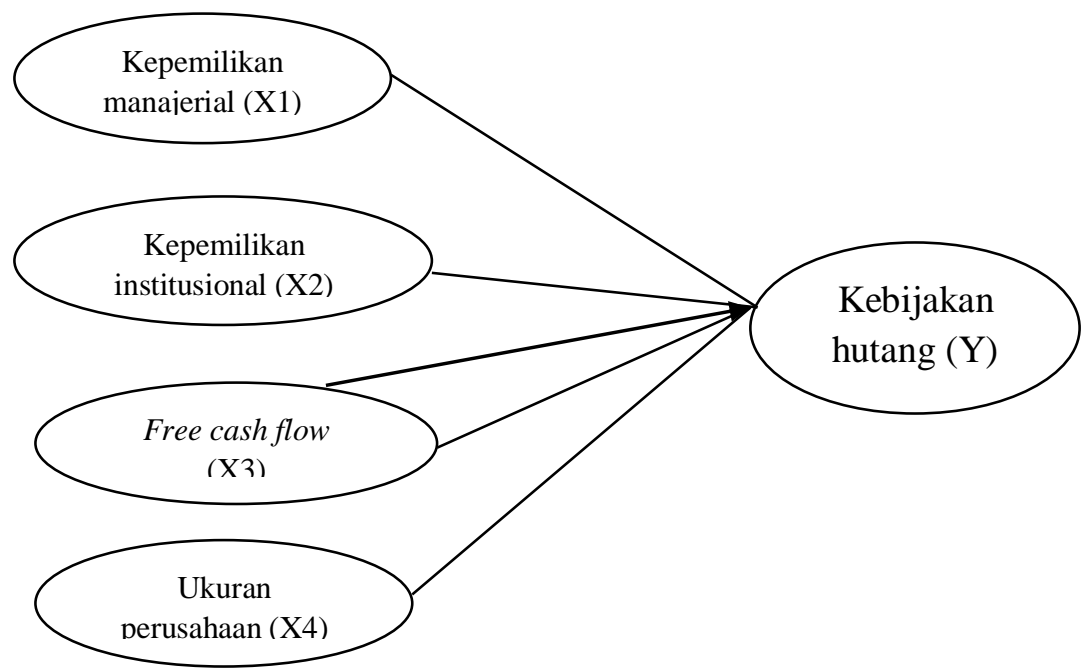

\section{METODE PENELITIAN}

Gambar 2.1 Kerangka konseptual

Jenis data dalam penelitian ini adalah data sekunder yang berupa data kuantitatif mengenai kepemilikan manajerial, kepemilikan institusional, free cash flow dan ukuran perusahaan. Data tersebut bersumber dari laporan keuangan yang dipublikasikan perusahaan manufaktur sektor industri kertas pada tahun 2010-2015 yang didapatkan dari situs BEI yang diakses melalui www.idx.co.id. Populasi yang digunakan dalam penelitian ini adalah seluruh perusahaan manufaktur sektor industri kertas yang terdaftar di BEI sebanyak 8 perusahaan.

Teknik pengambilan sampel dalam penelitian ini menggunakan purposive judgement sampling. Sampel ini dipilih berdasarkan kriteria tertentu, yaitu 1) Perusahaan manufaktur sektor industri kertas yang terdaftar di BEI periode 2010-2015, 2) Perusahaan manufaktur sektor industri kertas yang mempublikasikan laporan keuangan tahunan secara berturut-turut pada periode 2010-2015 yang terdaftar di BEI, 3) Perusahaan manufaktur yang memiliki free cash flow positif.

\section{Definisi operasional dan pengukuran variabel}

Variabel dependen penelitian ini adalah kebijakan hutang, yang disimnolkan dengan " $Y$ ". Kebijakan hutang secara sistematis dapat dirumuskan sebagai berikut:

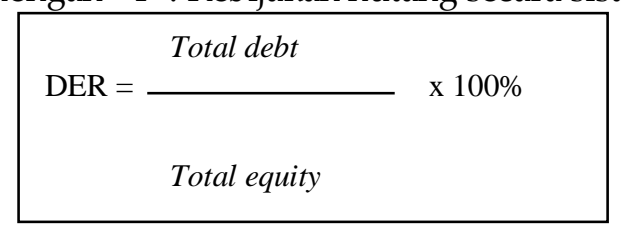

Sumber: Agustian (2014:9)

Penelitian ini menggunakan variabel independen yaitu kepemilikan manajerial, kepemilikan institusional, free cash flow, dan ukuran perusahaan.

\section{Kepemilikan Manajerial}

Kepemilikan manajerial adalah proporsi kepemilikan saham yang dimiliki oleh manajemen dan diukur dengan persentase saham yang dimiliki. Kepemilikan manajerial dirumuskan sebagai berikut:

\begin{tabular}{|c|c|}
\hline \multicolumn{2}{|c|}{ Jumlah saham yang dimiliki manajer dan dewan komisaris } \\
\hline KPM & $\mathrm{x} 100$ \\
\hline & \\
\hline
\end{tabular}


Sumber: Fransiska (2015:8)

\section{Kepemilikan Institusional}

Kepemilikan institusional adalah proporsi kepemilikan saham yang dimiliki oleh institusional pada akhir tahun yang diukur dalam persentase saham yang dimiliki oleh investor institusional suatu perusahaan. Kepemilikan institusional dirumuskan sebagai berikut:

\begin{tabular}{|cc|}
\hline KPI & \\
& Jumlah saham yang dimiliki institusi \\
Jumlah saham beredar & \\
\hline
\end{tabular}

\section{Free Cash Flow}

Penman (2009:38) mendefinisikan free cash flow adalah sebuah kas perusahaan yang didistribusikan kepada kreditur atau pemegang saham yang tidak diperlukan untuk modal atau investasi pada asset tetap. Free cash flow dirumuskan sebagai berikut:

$\mathrm{FCF}=\mathrm{CFO}-\mathrm{CFI}$

Sumber: Yulianto (2010:22)

\section{Ukuran Perusahaan}

Ukuran perusahaan akan menentukan sulit atau mudahnya suatu perusahaan mendapatkan pendanaan. Ukuran perusahaan juga mempengaruhi besar kecilnya tingkat pendanaan yang dilakukan. Ukuran perusahaan dirumuskan sebagai berikut:

Size $=$ LN $($ Total Asset $)$

Sumber: Anggraini (2013:9)

\section{Teknik Analisis Data}

Teknik analisis data yang digunakan dalam penelitian ini adalah analisis regresi berganda. Digunakan untuk mengetahui pengaruh antara variabel satu dengan yang lain. Untuk menguji dan menjelaskan apakah variabel independen berpengaruh terhadap variabel dependen, dengan menggunakan persamaan regresi sebagai berikut:

$\mathrm{Y}=\beta 0+\beta 1 \mathrm{X} 1+\beta 2 \mathrm{X} 2+\beta 3 \mathrm{X} 3+\beta 4 \mathrm{X} 4+\mathrm{e}$

Keterangan :

$\mathrm{Y}=$ Kebijakan Hutang

$\beta 0=$ Konstanta.

$\beta 1-\beta 4=$ Koefisien regresi dari setiap variabel independen.

X1 = Kepemilikan Manajerial

$\mathrm{X} 2$ = Kepemilikan Institusional

$\mathrm{X} 3=$ Free Cash Flow

$\mathrm{X} 4=$ Ukuran Perusahaan

Dalam menggunakan analisis regresi, pengujian asumsi klasik perlu dilakukan, agar hasil dari analisis regresi ini dapat menunjukkan hubungan yang valid.

- Uji Multikolinieritas 
Nurul Puspitasari, Pengaruh Kepemilikan Manajerial, Kepemilikan Institusional, Free Cash Flow Dan Ukuran Perusahaan Terhadap Kebijakan Hutang

Menurut Ghozali (2011:91) uji ini dilakukan untuk mengetahui apakah model regresi ditemukan adanya korelasi antar variabel bebas (independen). Model regresi yang baik seharusnya diantara variabel indepennya tidak terjadi korelasi. Untuk mendeteksi ada tidaknya suatu multikolinieritas dapat dilakukan dengan melihat nilai Varians Inflating Factor (VIF).Apabila nilai tolerance $>0,10$ atau sama dengan nilai VIF $<10$ berarti menunjukkan tidak terjadi multikolinieritas.

- Uji Autokorelasi

Uji ini dilakukan untuk mengetahui apakah model regresi ada korelasi antara kesalahan pengganggu pada periode $t$ dengan kesalahan pengganggu pada periode $t-1$ (sebelumnya) menurut Ghozali (2011:96). Autokorelasi ini terjadi akibat adanya residual tidak bebas dari satu penelitian ke penelitian lainnya. Dengan kata lain, masalah ini sering kali ditemukan apabila menggunakan data runtut waktu (Kuncoro, 2014:106). Autokrelasi diuji dengan menggunakan Durbin-Watson. Dengan kriteria, menurut Firdaus (2010:110), jika nilai Durbin Watson $=1,55-2,46$ menunjukkan tidak terjadi autokorelasi.

- Uji Heteroskedastisitas

Uji ini digunakan untuk menguji apakah model regresi terjadi ketidaksamaan variance dari residual satu pengamatan ke pengamatan lain (Ghozali, 2011:100). Model regresi yang baik tidak mendeteksi heteroskedastisitas, untuk mendeteksi heteroskedastisitas adalah dengan melihat grafik plot antara nilai prediksi variabel terikat (Dependen) yaitu SRESID dan nilai residualnya ZPRED. Kriterianya jika gambar scatterplot tidak membentuk suatu gambar tertentu maka tidak terjadi heteroskedastisitas.

- Uji Normalitas

Uji asumsi klasik normalitas ini bertujuan untuk menguji apakah di dalam model regresi, variabel pengganggu atau residual memiliki distribusi normal (Ghozali, 2011:103). Untuk menguji apakah residual berdistribusi normal atau tidak, test statistik yang digunakan adalah Kolmogorov Smirnov. Normal tidaknya distribusi data dapat dilihat dari nilai Asymp Sig (2-tailed), jika nilai Asymp Sig (2-tailed)> dari alpa 0.05 atau 5\% maka variabel pengganggu berdistribusi normal.

\section{Pengujian Hipotesis}

Untuk menguji hipotesis yang diajukan, digunakan uji $t$ untuk menguji dan menjelaskan apakah variabel independen secara parsial berpengaruh terhadap kebijakan hutang. Uji $\mathrm{t}$ dalam penelitian ini menggunakan tingkat signifikansi $5 \%$. Jika hasil signifikansi uji-t menunjukkan lebih kecil dari 5\% maka hipotesis akan diterima. Namun sebaliknya, jika hasil uji signifikansi uji-t menunjukkan hasil lebih besar dari 5\% maka hipotesis akan ditolak.

\section{HASIL DAN PEMBAHASAN}

\section{Uji Asumsi Klasik}

- Uji Multikolinieritas

Hasil uji asumsi klasik multikolinieritas dengan menggunakan pendekatan VIF (Variance Inflation Faktor) menunjukkan bahwa nilai VIF semua variabel $<10$ dan nilai Tolerance lebih dari 0,1 sehingga tidak terjadi multikolinieritas.

- Uji Autokorelasi 
Nurul Puspitasari, Pengaruh Kepemilikan Manajerial, Kepemilikan Institusional, Free Cash Flow Dan Ukuran Perusahaan Terhadap Kebijakan Hutang

Hasil uji asumsi klasik autokorelasi menunjukkan bahwa nilai Durbin Watson sebesar 1.989 terletak diantara 1,55-2,46. Hal tersebut mengindikasikan bahwa tidak terjadi autokorelasi.

- Uji Heteroskedastisitas

Hasil uji asumsi klasik heteroskedastisitas menunjukkan bahwa scatter plot tidak membentuk suatu gambar/pola tertentu, sehingga tidak terjadi heteroskedastisitas.

- Uji Normalitas

Hasil uji asumsi klasik normalitas menunjukkan bahwa nilai Asymp Sig (2-tailed) sebesar 0.692 melebihi 0.05 , hal ini menunjukkan bahwa variabel pengganggu/variabel yang tidak diteliti memiliki distribusi normal.

\section{Hasil Analisis Regresi Berganda}

Hasil analisis regresi berganda dapat dibuat persamaan regresi sebagai berikut:

$$
\begin{aligned}
\mathrm{Y} & =\beta 0+\beta 1 \mathrm{X} 1+\beta 2 \mathrm{X} 2+\beta 3 \mathrm{X} 3+\beta 4 \mathrm{X} 4+\mathrm{e} \\
& =2.240+0.047 \mathrm{X} 1+0.020 \mathrm{X} 2+0.057 \mathrm{X} 3+0.033 \mathrm{X} 4+\mathrm{e}
\end{aligned}
$$

Selanjutnya diringkas pada tabel 1 dibawah ini:

Tabel 1 Hasil Analisis Regresi Berganda

\begin{tabular}{|l|c|c|c|}
\hline \multicolumn{1}{|c|}{ Variabel } & $\begin{array}{c}\text { Koefisien regresi } \\
\text { yang sudah di } \\
\text { standarisasi }\end{array}$ & $\begin{array}{c}\text { Nilai } \\
\text { signifikansi }\end{array}$ & Kesimpulan \\
\hline $\begin{array}{l}\text { Variabel X1 (Kepemilikan } \\
\text { Manajerial) }\end{array}$ & 0.047 & .006 & Berpengaruh \\
\hline $\begin{array}{l}\text { Variabel X2 (Kepemilikan } \\
\text { Institusional) }\end{array}$ & 0.020 & .198 & Tidak Berpengaruh \\
\hline Variabel X3 (Free Cash Flow) & 0.057 & .000 & Berpengaruh \\
\hline $\begin{array}{l}\text { Variabel X4 (Ukuran } \\
\text { Perusahaan) }\end{array}$ & 0.033 & .027 & Berpengaruh \\
\hline Nilai R-square $=0.675$ & \multicolumn{5}{|l}{} \\
\hline
\end{tabular}

Berdasarkan persamaan regresi dan tabel 4.10 dapat dijelaskan sebagai berikut:

1. Koefisien regresi yang sudah di standarisasi atas kepemilikan manajerial (X1) yaitu sebesar 0.047. Koefisien regresi sebesar 0.047 menunjukkan hubungan yang positif antara variabel kepemilikan manajerial dengan kebijakan hutang. Artinya, apabila terjadi perubahan kepemilikan manajerial sebesar $1 \%$ maka kebijakan hutang akan mengalami kenaikan sebesar 0.047 (4.7\%).

2. Koefisien regresi yang sudah di standarisasi atas kepemilikan manajerial (X2) yaitu sebesar 0.020 . Koefisien regresi sebesar 0.020 menunjukkan hubungan yang positif antara variabel kepemilikan institusional dengan variabel kebijakan hutang. Artinya, apabila terjadi perubahan kepemilikan institusional sebesar 1\% maka kebijakan hutang akan mengalami kenaikan sebesar 0.020 (2.0\%).

3. Koefisien regresi yang sudah di standarisasi atas free cash flow (X3) yaitu sebesar 0.057 . Koefisien regresi sebesar 0.057 menunjukkan ada hubungan yang positif antara variabel free cash flow dengan variabel kebijakan hutang. Artinya, apabila terjadi perubahan free cash flow sebesar $1 \%$ maka kebijakan hutang akan mengalami kenaikan sebesar 0.057 (5,7\%).

4. Koefisien regresi yang sudah di standarisasi atas ukuran perusahaan (X4) yaitu sebesar 0.033. Koefisien regresi sebesar 0.033 menunjukkan ada hubungan yang positif antara variabel ukuran perusahaan dengan variabel kebijakan hutang. 
Nurul Puspitasari, Pengaruh Kepemilikan Manajerial, Kepemilikan Institusional, Free

Cash Flow Dan Ukuran Perusahaan Terhadap Kebijakan Hutang

Artinya, apabila terjadi perubahan ukuran perusahaan sebesar 1\% maka kebijakan hutang akan mengalami kenaikan sebesar 0.033 (3.3\%).

5. Nilai R-square 0.675 , menunjukkan bahwa perubahan variabel kebijakan hutang sebesar $67.5 \%$ dipengaruhi oleh variabel kepemilikan manajerial, free cash flow, dan ukuran perusahaan. Dan sisanya sebesar 23.5\% dipengaruhi oleh variabel lain yang tidak diteliti.

\section{Hasil Uji Hipotesis Pertama}

Berdasarkan tabel 1 di atas menunjukkan bahwa nilai signifikansi uji-t atas variabel kepemilikan manajerial sebesar 0.006 lebih kecil dari 5\%. Berarti, secara parsial variabel kepemilikan manajerial berpengaruh terhadap variabel kebijakan hutang. Sehingga hipotesis pertama yang menyatakan bahwa kepemilikan manajerial secara parsial berpengaruh terhadap kebijakan hutang diterima.

\section{Hasil Uji Hipotesis Kedua}

Berdasarkan tabel 1 diatas, menunjukkan bahwa nilai signifikansi uji-t atas variabel kepemilikan institusional sebesar 0.198 lebih besar dari 5\%. Berarti, secara parsial variabel kepemilikan institusional tidak berpengaruh terhadap kebijakan hutang. Sehingga hipotesis kedua yang menyatakan bahwa kepemilikan institusional secara parsial berpengaruh terhadap kebijakan hutang ditolak.

Hasil Uji Hipotesis ketiga

Berdasarkan tabel 1 di atas menunjukkan bahwa nilai signifikansi uji-t atas variabel free cash flow sebesar 0.000 lebih kecil dari 5\%. Berarti, bahwa secara parsial variabel free cash flow berpengaruh terhadap kebijakan hutang. Sehingga, hipotesis ketiga yang menyatakan bahwa free cash flow secara parsial berpengaruh terhadap kebijakan hutang diterima.

\section{$\underline{\text { Hasil Uji Hipotesis Keempat }}$}

Berdasarkan tabel 1 di atas menunjukkan bahwa nilai signifikansi uji-t atas variabel ukuran perusahaan sebesar 0.027 lebih kecil dari 5\%. Berarti, bahwa secara parsial variabel ukuran perusahaan berpengaruh terhadap kebijakan hutang. Sehingga, hipotesis keempat yang menyatakan bahwa ukuran perusahaan secara parsial berpengaruh terhadap kebijakan hutang diterima.

\section{$\underline{\text { Hasil Uji Hipotesis Kelima }}$}

Di dalam tabel 1 di atas menunjukkan bahwa dari ketiga variabel yang signifikan, yaitu kepemilikan manajerial, free cash flow dan ukuran perusahaan yang merupakan variabel paling dominan yaitu free cash flow karena nilai betanya paling besar yaitu 0.057. Sehingga, hipotesis kelima yang menyatakan bahwa free cash flow berpengaruh paling dominan diterima.

\section{Pembahasan}

Hasil penelitian menunjukkan bahwa nilai signifikansi uji-t atas variabel kepemilikan manajerial (X1) sebesar 0.006 bertanda positif. Dan nilai koefisien regresi yang sudah di standarisasi menunjukkan sebesar 0.047. Apabila terjadi perubahan kepemilikan sebesar 1\% maka kebijakan hutang akan mengalami kenaikan sebesar 0.047 
Nurul Puspitasari, Pengaruh Kepemilikan Manajerial, Kepemilikan Institusional, Free

Cash Flow Dan Ukuran Perusahaan Terhadap Kebijakan Hutang

(4.7\%). Hasil uji-t atas variabel kepemilikan manajerial sebesar 0.006 lebih kecil dari 5\%, yang artinya variabel kepemilikan berpengaruh terhadap variabel kebijakan hutang.Hasil penelitian ini berbeda dengan hasil penelitian yang dilakukan oleh Fransiska (2015), Saerang dkk (2015), Bernice (2015), Santosa (2014), Anggraini (2013) dan Joher (2006) yang menyatakan bahwa kepemilikan manajerial tidak berpengaruh terhadap kebijakan hutang. Namun, dalam penelitian ini menyatakan bahwa kepemilikan manajerial berpengaruh terhadap kebijakan hutang. Apabila perusahaan memiliki kepemilikan manajerial yang tinggi, maka dengan rangkap jabatan yang dimiliki akan membuat manajer dan pemegang saham lebih berhati-hati dalam pengambilan keputusan yang berhubungan dengan pendanaan menggunakan hutang. Pernyataan tersebut didukung oleh Wahyu (2008:7) menyatakan bahwa dengan adanya kepemilikan manajerial akan mensejajarkan kepentingan antara manajemen dan pemegang saham, karena manajer akan merasakan langsung terhadap keputusan yang akan diambil terutama keputusan mengenai hutang.

Hasil penelitian menunjukkan bahwa nilai signifikansi uji-t atas variabel kepemilikan institusional (X2) sebesar 0.198 bertanda positif. Dan nilai koefisien regresi yang sudah di standarisasi menunjukkan sebesar 0.020. Apabila terjadi perubahan kepemilikan institusional sebesar $1 \%$ maka kebijakan hutang akan mengalami kenaikan sebesar $0.020(2.0 \%)$. Hasil uji-t atas variabel kepemilikan institusional sebesar 0.198 lebih besar dari 5\%, yang artinya variabel kepemilikan institusional tidak berpengaruh terhadap variabel kebijakan hutang. Hasil penelitian ini berbeda dengan hasil penelitian yang dilakukan oleh Fransiska (2015), Saerang dkk (2015), Bernice (2015) yang menyatakan bahwa kepemilikan institusional berpengaruh terhadap kebijakan hutang. Namun, dalam penelitian ini kepemilikan institusional tidak berpengaruh terhadap kebijakan hutang. Hal ini menunjukkan bahwa kepemilikan institusional tidak termasuk komponen yang signifikan dalam kebijakan hutang. Kepemilikan institusional hanya dapat memonitoring kinerja manajemen. Pernyataan tersebut didukung oleh Anggraini (2013:5) menyatakan bahwa dengan tingginya kepemilikan institusional suatu perusahaan akan meningkatkan pengawasan terhadap kinerja yang dilakukan oleh manajemen.

Hasil penelitian menunjukkan bahwa nilai signifikansi uji-t atas variabel free cash flow (X3) sebesar 0.000 bertanda positif. Dan nilai koefisien regresi yang sudah di standarisasi menunjukkan sebesar 0.057. Apabila terjadi perubahan free cash flow sebesar 1\% maka kebijakan hutang akan mengalami kenaikan sebesar 0.057 (5.7\%). Hasil uji-t atas variabel free cash flow sebesar 0.000 lebih kecil dari 5\%, yang artinya variabel free cash flow berpengaruh terhadap variabel kebijakan hutang. Semakin besar free cash flow perusahaan maka semakin besar pula kemampuan perusahaan dalam membayar hutang. Pernyataan tersebut didukung oleh pernyataan Jensen (1986:4) yang menyatakan dengan free cash flow yang besar akan dapat digunakan untuk pertumbuhan, pembayaran hutang dan dividen.

Hasil penelitian menunjukkan bahwa nilai signifikansi uti-t atas variabel ukuran perusahaan (X4) sebesar 0.027 bertanda positif. Dan nilai koefisien regresi yang sudah di standarisasi menunjukkan sebesar 0.033. Apabila terjadi perubahan ukuran perusahaan sebesar 1\% maka kebijakan hutang akan mengalami kenaikan sebesar 0.033 (3.3\%). Hasil uji-t atas variabel ukuran perusahaan sebesar 0.027 lebih kecil dari 5\%. Yang artinya variabel ukuran perusahaan berpengaruh terhadap variabel kebijakan hutang. Hasil penelitian ini mendukung penelitian yang dilakukan oleh Anggraini (2013). Semakin besar ukuran perusahaan, semakin tinggi pula tingkat penggunaan hutang karena besar 
Nurul Puspitasari, Pengaruh Kepemilikan Manajerial, Kepemilikan Institusional, Free

Cash Flow Dan Ukuran Perusahaan Terhadap Kebijakan Hutang

kecilnya perushaaan berpengaruh terhadap seberapa besar modal yang digunakan.Pernyataan tersebut didukung oleh pernyataan Anggraini, (2013:7) yang menyatakan bahwa semakin besar ukuran perusahaan akan cenderung menggunakan modal yang besar juga, karena perusahaan besar membutuhkan modal yang besar.

\section{KESIMPULAN}

Berdasarkan pengujian dan penjelasan yang telah dilakukan pada bab sebelumnya, dapat disimpulkan bahwa variabel kepemilikan manajerial secara parsial berpengaruh terhadap kebijakan hutang, variabel kepemilikan institusional secara parsial tidak berpengaruh terhadap kebijakan hutang, variabel free cash flow secara parsial berpengaruh terhadap kebijakan hutang, variabel ukuran perusahaan secara parsial berpengaruh terhadap kebijakan hutang, dan variabel free cash flow berpengaruh dominan terhadap kebijakan hutang.

Bagi peneliti selanjutnya, sebaiknya menggunakan perusahaan selain perusahaan manufaktur sebagai populasi penelitian untuk menguji lebih jelas bagaimana hasil dari faktor-faktor yang mempengaruhi kebijakan hutang .

\section{DAFTAR PUSTAKA}

Agustian, Gian Ginanjar, 2014, Pengaruh Kepemilikan Manajerial, Kepemilikan Institusional, dan Kebijakan Deviden Terhadap Kebijakan Hutang Perusahaan, Hal 1-18.

Anggraini, Novi, 2013, Pengaruh Kepemilikan Manajerial, Kepemilikan Institusional, Kebijakan Deviden dan Ukuran Perusahaan Terhadap Kebijakan Hutang, Hal 120.

Arikunto, S, Prosedur Penelitian: Suatau Pendekatan Praktik, Jakarta: Rineka Cipta.

Bernice, Yezia, 2015, The Impact of Managerial Ownership, Institutional Ownership and Company Size Towards Debt Equity, IBEA International Conference on Business, Economics and Accounting.

Bodie, Zvi, Alex Kane, Alan J. Marcus, 2010, Investasi, Alih bahasa oleh Zuliani Dalimunthe dan Budi Wibowo, Jakarta: Salemba Empat.

Fahmi, Irham, 2012, Analisis Laporan Keuangan, Bandung:Alfabeta.

Firdaus, M, 2010, Ekonomika Suatu Pendekatan Aplikatif, Bandung: Bumi Aksara.

Fransiska, Yuli, 2015, Pengaruh Kepemilikan Institusional, Kepemilikan Manajerial, dan Kebijakan Deviden terhadap Kebijakan Hutang Pada Perusahaan Manufaktur yang Terdaftar Di Bursa Efek Indonesia Tahun 2012-2014,Journal Riset Mahasiswa, ISSN 2337-56, Vol. xx, No xx hal 1-15.

Ghozali, Imam, 2011, Aplikasi analisis multivariate dengan program IBM SPSS 19, Edisi Kelima, Universitas Diponegoro, Semarang.

Jensen, Michael C, 1986, Agency Costs of Free Cash Flow, Corporate Finance, and Takeovers, American Economic Review, May 1986, Vol. 76, No. 2, pp. 323-329

Joher, Huson, 2006, The Impact of Ownership Structure on Corporate Debt Policy: Two Stage Least Square Simultaneous Model Approach For Post Crisis Period: 
Nurul Puspitasari, Pengaruh Kepemilikan Manajerial, Kepemilikan Institusional, Free Cash Flow Dan Ukuran Perusahaan Terhadap Kebijakan Hutang

Evidence From Kuala Lumpur Stock Exchange, International Business \& Economics Research Journal.

Patricia, Mayang, 2014, Pengaruh Kepemilikan Institusional, Kepemilikan Manajerial, Set Kesempatan Investasi, dan Arus Kas Bebas Terhadap Kebijakan Utang Perusahaan, Skripsi, Fakultas Ekonomika dan Bisnis Universitas Diponegoro Semarang

Saerang, Ardika dan Sientje, 2015, Pengaruh Kepemilikan Manajerial dan Institusional Terhadap Kebijakan Hutang Pada Perusahaan Non Manufaktur Di BEI, Jurnal Berkala Ilmiah Efisiensi, Vol 15, No 05 hal 690-702.

Tarjo dan Jogiyanto, 2003, Analisis Free Cash Flow dan Kepemilikan manajerial terhadap kebijakan hutang pada perusahaan publik di Indonesia, SNA VI: Ikatan Akuntan Indonesia

Wahyu, Bagus Guntur, 2008, Pengaruh Manajerial dan Kepemilikan Institusional Terhadap Kebijakan Hutang pada Perusahaan Manufaktur di BEI.

Yulianto, Ari Hidayat, 2010, Pengaruh Kepemilikan Institusional, Free Cash Flow dan Kebijakan Deviden Terhadap Kebijakan Utang Perusahaan, Skripsi Fakultas Ekonomi Universitas Sebelas Maret Surakarta. 